\section{Treatment of Resorbed Mandibles with Titanium Plate and ImmediateImplant- Supported Prosthesis - Case Series}

\author{
Vinicius Fabris ${ }^{1}{ }^{0}$, Vagner Flavio Reginato ${ }^{2,3}{ }^{\circ}$, Carolina Smaniotto $^{2}{ }^{\circ}$, Atais
}

Bacchi $^{2}$, Rafael Leonardo Xediek Consani ${ }^{3}$ (1)
'Department of Oral Surgery, IMED - Faculdade Meridional, Passo Fundo, RS, Brazil ${ }^{2}$ Graduate Program in Dentistry, IMED - Faculdade Meridional, Passo Fundo, RS, Brazil ${ }^{3}$ Department of Prosthodontics and Periodontics, Piracicaba Dental School, UNICAMP - Universidade Estadual de Campinas, Piracicaba, SP, Brazil

Correspondence: Dr. Rafael Leonardo Xediek Consani, Avenida Limeira, 901, 13414-903 Piracicaba, SP, Brasil. Tel: +55-19-2106-5296. e-mail: rconsani@fop.unicamp.br

Key Words: implants, complete-arch prosthesis, mandibular fracture.
Severely resorbed mandibles with only cortical bone remaining can fracture during or after implant placement. This case series presents a technique to reduce the risk or the consequences of mandibular fracture. Seven patients with only cortical mandibular bone remaining were treated with the fixation of a titanium plate in the frontal surface previously to implant placement, during the same surgical procedure. Immediate completearch implant supported prosthesis were installed. Patient's systemic and local conditions that could influence implant survival were registered previously to surgery and during the follow up period. Biological and biomechanical complications were recorded. The condition of peri-implant tissues was evaluated. The follow-ups ranged from 12 to 84 months. Twenty-nine implants were placed and no implant failure or other biological complication was observed. The peri-implant tissue evaluation demonstrated most implants was surrounded by keratinized tissue (89.5\%). No marginal recession (implant platform cervical to gingival margin) was observed. Probing depth was normal, ranging from 0 to $3 \mathrm{~mm}$. Low scores of plaque index or bleeding on probing were recorded. Biomechanical complications evolved loosening of 4 prosthetic screws and 1 fractured. The use of a titanium plate for the fixation of severely resorbed mandibles with only cortical bone remaining was a safe treatment procedure, avoiding biological and major biomechanical complications in the treatment with immediate complete-arch implantsupported prosthesis.

\section{Introduction}

Rehabilitations with dental implants have been widely used in Dentistry, presenting high success rates (1). The treatment for edentulism through completearch implant-supported prosthesis aims to overcome the limitations of the conventional mucossuported treatment. The main shortcomings of conventional complete dentures are related to prosthetic instability due to the continuous alveolar bone reabsorption, which might reduce masticatory efficiency, cause masticatory pain, and phonetic impairment (2).

The reabsorption of the alveolar bone is characterized as a chronic, continuous, and multifactorial process, which involves local and systemic factors. The use of removable mucossupported prosthesis favors the process of bone resorption due to the transmission of the occlusal forces to the alveolar ridge, generating compression (3).

The fracture of mandibles treated with complete-arch implant-supported prosthesis has been reported in the literature $(4,5)$. It can generate great complications such as paresthesia, osteomyelitis, malunion, non-union, and prolonged functional and nutritional problems $(4,6)$. Some systemic factors such as osteoporosis or other calcium-related deficiencies might favor the bone fracture. Postmenopausal women were considered with greater risk of bone fracture in previous studies (4). The risk of fracture is greater when only cortical bone is present, because the structure is much more fragile. However, no study in literature has focused in this group of patients.

When the mandibular fracture occurs during implant placement, it is necessary immediate reduction and immobilization, which limits the implant placement at the same surgical procedure. The mandibular fracture may also occur after surgery, during function, as the presence of implants weaken the severely resorbed mandible (7). This would lead to the need for a new surgical procedure, immediate mandibular fixation and, in most cases, the removal of the implant, because the fractured region is usually at the bone-implant interface. This might lead consequently to the loss of the prosthesis.

The clinical procedures presented in this case series were introduced to avoid the consequences mentioned previously. This technique consists in the fixation of a titanium plate in the frontal surface of the mandible previously to the implant placement, during the same 
surgical procedure. Therefore, if the mandible breaks during the implant placement or after, during function, the mandible is already reduced, avoiding the several complications mentioned. The objective of this study was to report the survival of implants, periodontal characteristics and the biological and prosthetic complications treated with the above-mentioned technique.

\section{Material and Methods}

The local ethics committee approved this study (\#262.935/2013). Seven patients were treated with mandibular immediate complete-arch implantsupported prosthesis with a titanium plate fixed at the frontal surface of mandible previously to the implant placement, because only a severely resorbed cortical bone did exist (Misch's D category - bone at basal level), from December 2010 to December 2016. Twenty-nine implants were placed (5 implants in 1 patient and 4 implants for each one of the other 6 patients) in 3 men and 4 women. Participants had a mean age of $63.8 \pm 6.4$ years. The follow up periods ranged from 12 to 84 months. Patients 1, 2, 3, 4, 5, 6, 7 had follow-up periods of $84,56,55,42,34,20$, and 12 months, respectively. All participants aged 18 years or older. Patients were not excluded from the study because of possible medical and behavioral history or habits.

\section{Treatment Description}

The surgical procedure was performed in hospital environment with general anesthesia (Propofol 2.5 $\mathrm{mg} / \mathrm{kg}$, Cisatracúrio $0.15 \mathrm{mg} / \mathrm{kg}$, and Remifentanil 1.0 $\mathrm{mcg} / \mathrm{kg}$ ) and nasotracheal intubation. Local anesthesia (Lidocaine 2\%, 1:200,000) was used to improve vasoconstriction. Antibiotic (Cephalexin $500 \mathrm{mg}$ ) and anti-inflammatory (dexamethasone $4 \mathrm{mg}$ ) medications

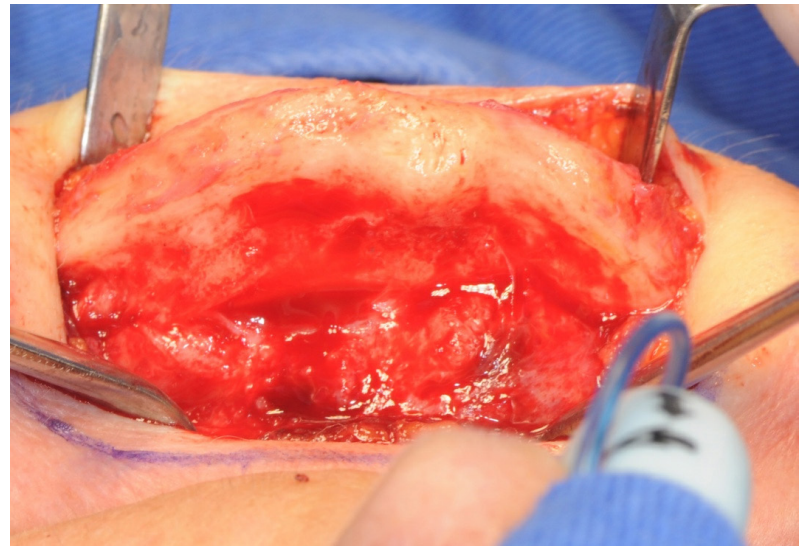

Figure 2. Mandible exposed. were ministered preoperatively. An extraoral incision was performed in the lower anterior region of mandible (Fig. 1), with bone exposure (Fig. 2). A rectangular titanium plate (17-hole reconstruction plate, Ref 926.005) (NEOORTHO, Curitiba, PR, Brazil) previously modeled in a mandible prototype was fixed in the frontal surface of mandible with titanium screws $(\emptyset 2.4 \times 8 \mathrm{~mm}$, Ref 925.002) (NEOORTHO) (Fig. 3).

The implant site preparation and implant placement were performed according to the implant manufacturer's instructions (Fig. 4). Mini conical abutments were connected to the implants (Fig. 5). In some cases, due to limited mandibular height, guided-bone regeneration was performed, as in the illustrated case. Therefore, deproteinized bovine bone mineral (Bio-oss; Geistlich Pharma) was adapted around the implants and covered with a resorbable membrane (bio-guide; Geistlich

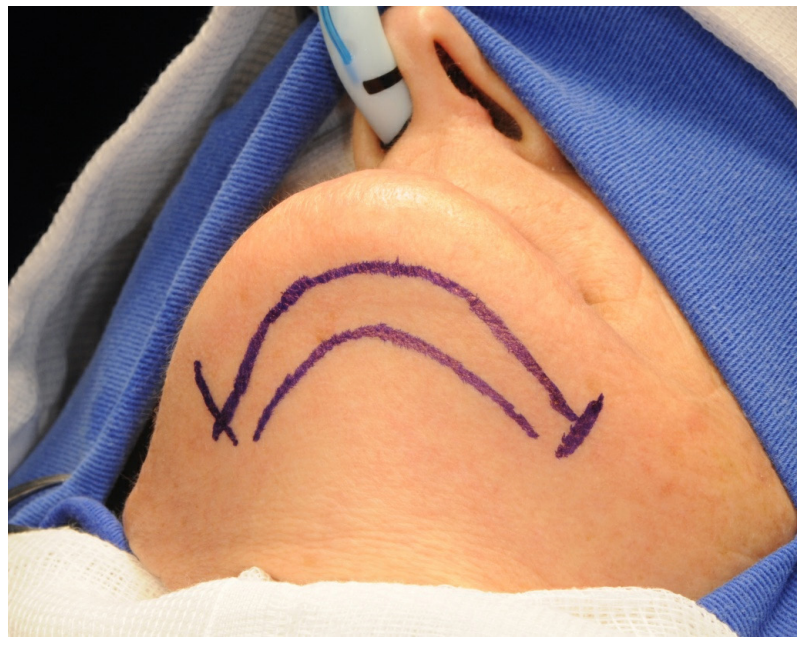

Figure 1. Local of extraoral incision demarcated.

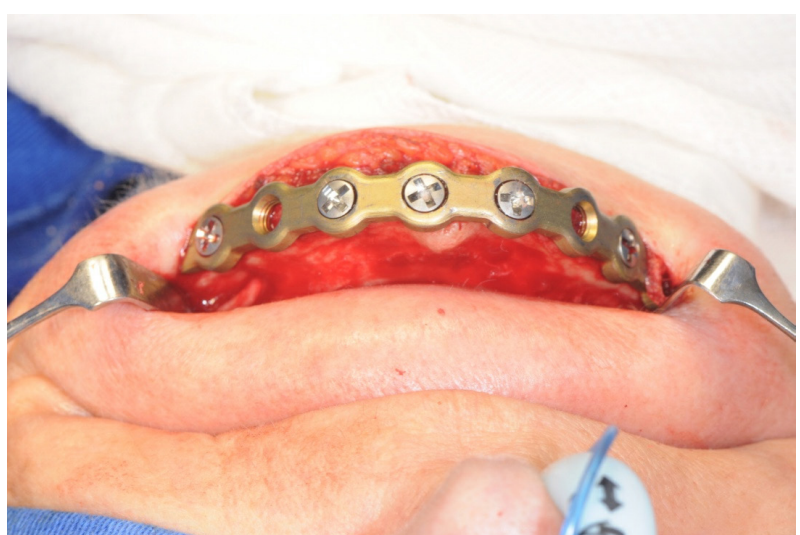

Figure 3. Titanium plate fixation in frontal surface of mandible. 
Pharma) (Fig. 6). The periosteum was sutured with resorbable and the skin with a nonresorbable suture. The post-surgical medications administered were Cephalexin (500 mg), Nimesulide (100 mg), and Paracetamol (750 $\mathrm{mg})$.

The conical abutments were assessed intraorally (Fig. 7). The prosthetic impression and maxillo-mandibular record were performed with the aid of a surgical template. A metal-acrylic immediate complete-arch implant-supported prosthesis was confectioned and installed after $72 \mathrm{~h}$. Panoramic radiographic exams (Fig.

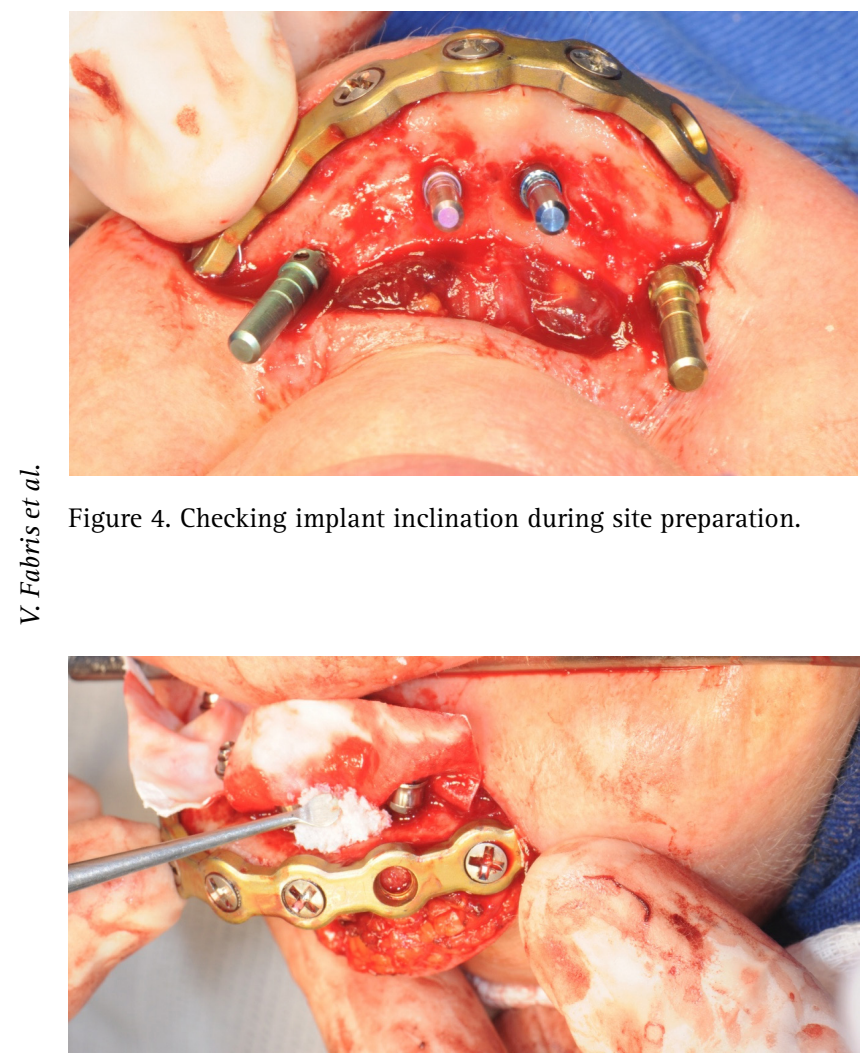

Figure 6. Guided bone regeneration.

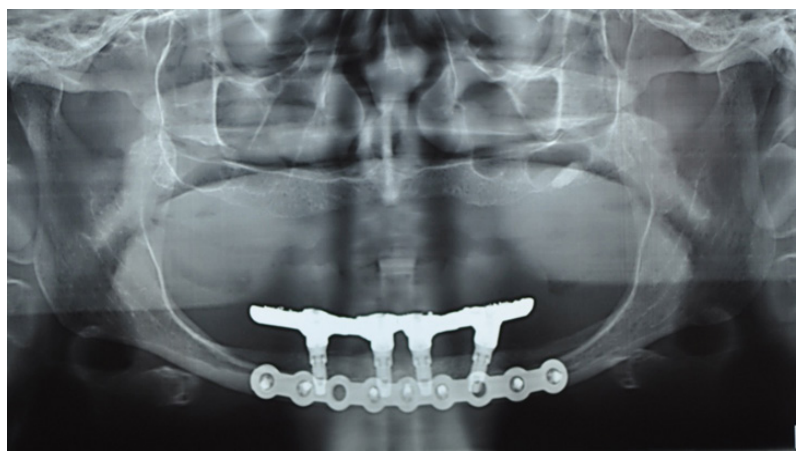

Figure 8. Panoramic radiograph after surgical procedure and prosthetic confection.
8) and intraoral photographs (Fig. 9) were taken after surgery and in the final follow up (12 months).

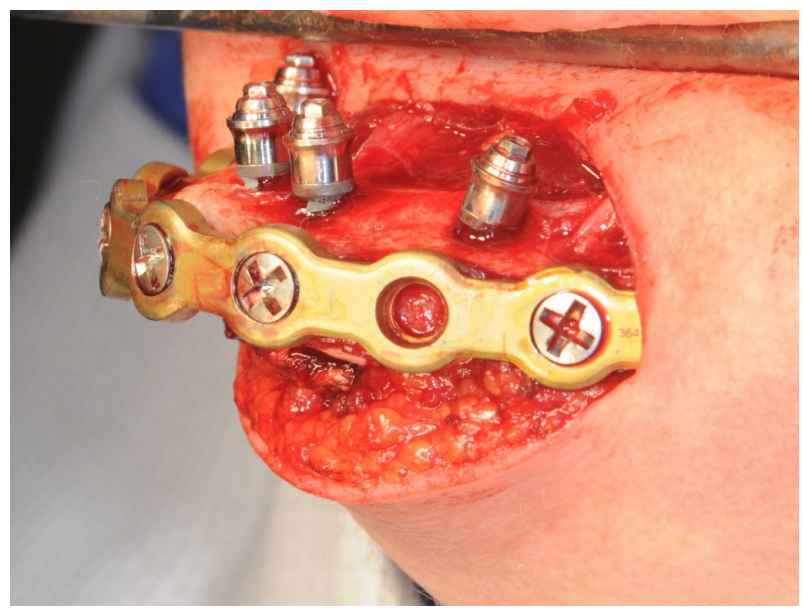

Figure 5. Implants placed in the region of teeth \#44, \#42, \#32, \#34, with respective abutments.

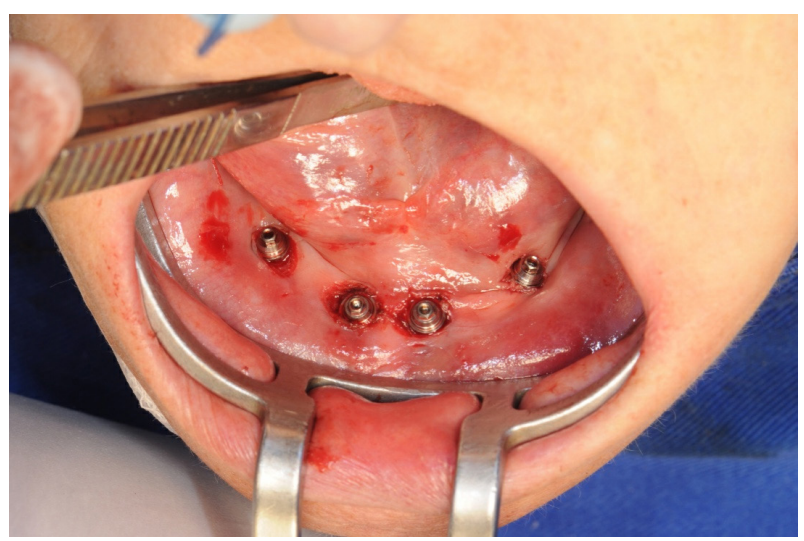

Figure 7. Mini conical abutments assessed intraorally.

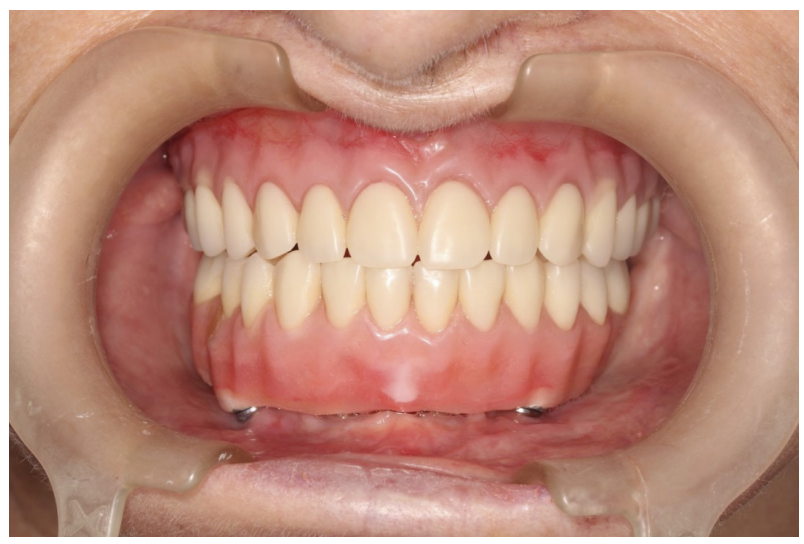

Figure 9. Intraoral view after 12 months of follow up. 


\section{Data Collection}

Systemic Factors. Parameters that could influence implant survival were registered. Information involved patient medical and behavioral history, smoking habits, alcoholism, radiotherapy, and history of periodontal disease. Clinical signs of bruxism were also considered (patients who presented wear facets, complained about muscle pains or reported grinding during sleep were considered as bruxers).

Implant-Related Factors. Information was obtained about implant length, diameter, connection, shape, surface treatment, guided bone regeneration, and initial implant stability.

Prosthesis-Related Factors and Maintenance. Prosthesis-related information involved material of confection, type of abutment, antagonist arch, prosthesis or screw fracture, screw loosening, hygiene difficulty, splint use, and maintenance were informed to the patients.

\section{Clinical Parameters}

The following clinical parameters were evaluated during the follow up visit:

Probing depth (PD) in millimeters: The presence of keratinized tissue (KT) at the midpoint of the buccal site of the implant (mm). The mucogingival line was taken as the apical limit. KT scores were categorized as absent, $>0$ and $\leq 2$, or $>2$;

Marginal recession (MR) (in $\mathrm{mm}$ ): The implant platform was considered as the cervical reference for marginal recession. MR was categorized as absent, $>0$ and $\leq 1,>1$ and $\leq 2$, or $>2 \mathrm{~mm}$;

Modified plaque index (MPi) at four aspects around the implants: score 0 , no detection of plaque; score 1 , plaque only recognized by running a probe across the smooth marginal surface of the implant; score 2, plaque can be seen by the naked eye; and score 3 , abundance of soft matter $(8,9)$;

Modified sulcus bleeding index (MSBi) at four aspects around the implants: score 0 , no bleeding when a periodontal probe is passed along the gingival margin adjacent to the implant; score 1, isolated bleeding spot visible; score 2, blood forms a confluent red line on margin; and score 3 , heavy or profuse bleeding $(8,9)$.

All prostheses were removed prior to the clinical examination to ensure accurate data collection. Measurements for MPi, PD, MSBi, and MR were obtained at six sites (mesiobuccal, midbuccal, distobuccal, mesiolingual, midlingual, and distolingual). An average value of the six measurements was calculated for each implant. All the clinical parameters were obtained using a periodontal probe (PCV12PT; Hu-Friedy Inc.). A single and experienced examiner (V. F.) performed the measurements in order to reduce errors and establish reliability and consistency (9).

\section{Results}

Concerning the patient risk factors, all participants presented at least one or a combination of controlled systemic diseases that could influence implant survival, as presented in Table 1. Six participants had history of periodontal disease. Other local or systemic risk factors were not observed (Table 1).

About the implant characteristics (Table 2), all 29 implants placed had a sandblasted and acid-etched surface, and 25 of which were cylindrical shaped. Twenty-four had external hexagon platforms and diameter of $3.75 \mathrm{~mm}$. Implant length varied from 8.0 to $11.5 \mathrm{~mm}$, mostly with $9 \mathrm{~mm}$ (8 implants) or $10 \mathrm{~mm}$ (15 implants). Guided bone regeneration was performed in two patients (8 implants). All implants were placed with initial implant stability above $35 \mathrm{~N} . \mathrm{cm}$. No implant was lost during the follow up.

Concerning prosthetic characteristics (Table 2), metal-acrylic prostheses were confectioned in the mandibular arches, in all cases opposing acrylic structures (6 mucossuported and 1 implant-supported complete denture). All participants wore a nocturnal interocclusal splint. No tooth, acrylic, or framework fracture was observed during the follow up. Mini conical abutments were used to connect the prosthesis to the implants. Mechanical complications identified were 1 screw fracture and 4 screw loosening. Even though the recall for maintenance was performed every 6 months, most of participants presented to less than one maintenance per year. The subjects did

Table 1. Patients' systemic condition and exposure to risk factors to implant failure

\begin{tabular}{lc}
\hline Systemic disease & Frequency \\
\hline Hypertension & 04 \\
Cholesterol & 03 \\
Hypothyroidism & 02 \\
Anxiety & 02 \\
Osteoporosis & 02 \\
Hepatitis B & 01 \\
Depression & 01 \\
Smoking habits & None \\
Alcoholism & None \\
Historic of periodontal disease & 06 \\
Radiotherapy & None \\
Bruxism & None \\
\hline
\end{tabular}


not report high hygiene difficulty.

The peri-implant tissue evaluation (Table 3) showed

Table 2. Information about implant and prosthetic factors

\begin{tabular}{|c|c|c|c|}
\hline $\begin{array}{l}\text { Implant } \\
\text { information }\end{array}$ & Frequency & $\begin{array}{l}\text { Prosthetic } \\
\text { information }\end{array}$ & Frequency \\
\hline \multirow{2}{*}{$\begin{array}{l}\text { Total number } \\
\text { of implants }\end{array}$} & \multirow[t]{2}{*}{29} & \multicolumn{2}{|c|}{ Type of mandibular prosthesis } \\
\hline & & $\begin{array}{l}\text { Metal-acrylic } \\
\text { resin }\end{array}$ & 7 \\
\hline \multicolumn{4}{|l|}{ Diameter } \\
\hline 3.5 & 4 & Type of abutment & \\
\hline 3.75 & 24 & $\begin{array}{l}\text { Mini conical } \\
\text { abutment }\end{array}$ & 29 \\
\hline \multirow[t]{2}{*}{4.3} & 1 & & \\
\hline & & Antagonist arch & \\
\hline Length & & $\begin{array}{l}\text { Muco-supported } \\
\text { denture }\end{array}$ & 6 \\
\hline 11.5 & 2 & $\begin{array}{l}\text { Implant- } \\
\text { supported denture }\end{array}$ & 1 \\
\hline 10 & 15 & & \\
\hline 9 & 8 & $\begin{array}{l}\text { Tooth or acrylic } \\
\text { resin fracture }\end{array}$ & None \\
\hline \multirow[t]{2}{*}{8} & 4 & & \\
\hline & & $\begin{array}{l}\text { Framework } \\
\text { fracture }\end{array}$ & None \\
\hline \multicolumn{4}{|l|}{ Surface treatment } \\
\hline $\begin{array}{l}\text { Sandblasted and } \\
\text { acid-etched }\end{array}$ & 29 & Screw fracture & 1 \\
\hline Shape & & Screw loosening & 4 \\
\hline Cylindrical & 25 & & \\
\hline \multirow[t]{2}{*}{ Conical } & 4 & Hygiene difficulty & \\
\hline & & Low & 6 \\
\hline $\begin{array}{l}\text { Prosthetic } \\
\text { connection }\end{array}$ & & Medium & 1 \\
\hline External hexagon & 24 & & \\
\hline Internal hexagon & 1 & Splint use & 7 \\
\hline \multirow[t]{2}{*}{ Morse taper } & 4 & & \\
\hline & & Maintenance & \\
\hline $\begin{array}{l}\text { Simultaneous } \\
\text { guided bone } \\
\text { regeneration }\end{array}$ & 8 & $\begin{array}{l}\text { More than } \\
\text { one per year }\end{array}$ & 1 \\
\hline $\begin{array}{l}\text { Initial implant } \\
\text { stability }\end{array}$ & & Once a year & 1 \\
\hline$>35$ N.cm & 29 & $\begin{array}{l}\text { Less than } \\
\text { once a year }\end{array}$ & 5 \\
\hline Lost implants & None & & \\
\hline
\end{tabular}

that most implants was surrounded by keratinized tissue (89.5\%), ranging predominantly from $>0$ to $\leq 2 \mathrm{~mm}(79 \%)$. No marginal recession (implant platform cervical to tissue) was observed. Probing depth ranged from 0 to $3 \mathrm{~mm}$, being most cases in the range $>2$ to $\leq 3 \mathrm{~mm}(66 \%)$. In the plaque index evaluation, the score I predominated (76\%) since plaque was mostly recognized only when running the probe across the marginal surface of the implant. In the MSBi evaluation, no bleeding on probing (52\%) and isolated bleeding spot visible (45\%) predominated, respectively.

No biological or biomechanical complication, such as mandible infection or fracture, was observed during the follow up.

Table 3. Data of peri-implant tissue evaluation

\begin{tabular}{lc}
\hline Keratinized tissue & Frequency / (\%) \\
\hline Absent & $3 /(10.5)$ \\
$>0$ e $\leq 2 \mathrm{~mm}$ & $23 /(79)$ \\
$>2 \mathrm{~mm}$ & $3 /(10.5)$
\end{tabular}

Marginal recession

Absent

$29 /(100)$

$>0$ e $\leq 1 \mathrm{~mm}$

$>1 \mathrm{e} \leq 2 \mathrm{~mm}$

$>2 \mathrm{~mm}$

Probing depth

$>0$ e $\leq 1 \mathrm{~mm}$

$3 /(10)$

$>1 \mathrm{e} \leq 2 \mathrm{~mm}$

7 / (24)

$>2$ e $\leq 3 \mathrm{~mm}$

$19 /(66)$

$>3$

Plaque index

$2 /(7)$

I

$22 /(76)$

II

$5 /$ (17)

III

Bleeding on probing

0

$15 /(52)$

I

$13 /(45)$

II

$1 /(3)$ 


\section{Discussion}

Bone reabsorption occurs continuously after tooth loss, causing significant reduction of the vertical and horizontal dimensions of the ridge. This might cause severe reabsorption of the jaws and presence of only cortical bone, which increases the risk of mandibular fracture associated with implant placement $(4,5)$. Because of this, the mandibular fixation technique was developed to improve the prognosis of immediate complete-arch implantsupported prosthesis. The presence of the titanium plate is useful to avoid fractures during the implant placement or maintain the bone fixed if the fracture occurred (10). If the mandibular fracture occurs after the surgical procedure, during function, the fixation avoids also the need for a new surgical procedure for repair (10). It might also prevent the loss of the implant involved in the region of fracture. The subjects of this study did not present any mandibular complication such as fracture or inflammation. All patients reported being satisfied with the treatment, without any report of functional pain, limitation, or discomfort.

No implant was lost in the evaluated patients. According to previous studies, the success of dental implants depends on several risk factors. Among these factors are systemic diseases, depression, chronic periodontitis, head and neck radiotherapy, lack of initial implant stability, bruxism, smoking habits, hygiene, and short-length implants (11). In this study, all participants presented at least one systemic disease considered as risk factor in the literature. However, all participants were controlled by medications and were submitted routinely to exams to check the disease condition. History of periodontal disease was present in $85 \%$ of the patients. However, besides it has been considered a risk factor in some analysis (12), other studies presented high survival rates and no difference in the survival rates of implants placed in patients with history of periodontitis compared to patients not affected (13). The absence of bruxism, smoking habits, high hygiene limitation, radiotherapy, or initial implant stability below the recommended for immediate loading (35 N.cm) might also help to explain the absence of implant failure.

The use of short or extra-short dental implants can be avoided in most cases when the mandibular fixation technique is adopted. In this study, the presence of the titanium plate allowed to the use of implants with lengths ranging from 8.0 to $11.5 \mathrm{~mm}$ and, because mandibular resorption is predominantly vertical, it was possible to place implants with regular diameter. Some studies have shown higher failure rates with short dental implants when compared with standard length implants (14). However, a systematic review has shown greater risk only for extrashort implants (those shorter than $6 \mathrm{~mm}$ ) (15). Regarding the implant surface, all implants placed were sandblasted and acid-etched. Studies report that the use of implants with moderately rough surfaces significant improve the early biological response to osseointegration, providing greater predictability of success (16).

The correct dissipation of the masticatory load might be an important factor for the clinical success of implantsupported rehabilitations. This is specifically important in the present scenario evaluated, due to the fragile characteristic of the cortical-only resorbed mandibles. These observations include considerations about prosthetic material, components, and antagonist arch. According to previous reports, the use of acrylic resin as a veneering material for the implant-supported prosthesis is more efficient to reduce the stresses in bone tissue, implants, and prosthetic structures when compared to ceramics, due to its lower Young's modulus (17). As antagonists, 6 patients had a mucossupported denture and another a metal-acrylic complete-arch implant-supported prosthesis. That also leads to lower stresses in the implant-supported prosthesis and supporting structures when compared to ceramics or natural dentition as antagonists (17). In addition, all participants wore a nocturnal interocclusal splint to protect the rehabilitation from oblique loads or concentrated contacts. In all cases, mini conical abutments were used to connect the prosthesis to the implants. The use of abutment optimizes the dissipation of occlusal loads through prosthetic and biologic structures when compared to prosthesis connected directly to the implants (18).

Regarding the biomechanical complications observed during the follow-up, the loosening of 4 prosthetic screws and 1 screw fracture were recorded. These complications are commonly observed in clinical practice. Previous studies have reported that screw loosening is one of the most frequent complications in implant-supported rehabilitations (19). A systematic review included also screw fracture as one of the most common mechanical complications in complete-arch implant-supported prosthesis (20).

No biological complications were identified in this study. Biological complications have been reported in the literature as the most frequent cause of failure of dental implants (21). Among the complications are the periimplant mucositis and peri-implantitis, which generate inflammation of soft and hard peri-implant tissues, followed by bone loss (21). The presence of peri-implant KT is one factor pointed as important for a better prognosis in rehabilitations with dental implants (22). In a retrospective study, it was observed that the absence of peri-implant KT was associated with gingival inflammation and bacterial plaque accumulation (23). According to another report, implants that did not have peri-implant KT were more prone to plaque accumulation and MR, even in patients 
with adequate hygiene and periodically maintenance (22). In this study, KT was present around most implants (89.5\%), predominantly in a range $>0$ to $\leq 2 \mathrm{~mm}(79 \%)$. This data associated with the low difficulty for hygiene reported by the patients can explain the absence of MR, low MPi score, and low bleeding on probing. MPi predominated in score I (76\%) followed by scores II (17\%), and 0 (7\%). These data are in agreement with a previous study that evaluated complete-arch implant-supported mandibular prosthesis (24), where score I predominated and scores II and 0 presented low percentage.

The absence of bleeding on probing (52\%) predominated in the MSBi evaluation. The isolated bleeding points visible (score I, 45\%) were comparable to a previous report that showed a range from 41.4 to $45.7 \%$ in this score (13). According to a follow-up of 9 to 14 years in implant treatments, PD levels and pocket formation may be more common in areas without KT (25). This might explain the adequate PD obtained in this study, where $100 \%$ of sites had measures $>0$ and $\leq 3 \mathrm{~mm}$. The PD values of the present evaluation are comparable of those of a previous study in complete-arch implant-supported rehabilitation in which mean values between 2 and $3 \mathrm{~mm}$ predominated (13).

Different from the conventional technique for full-arch implant-supported rehabilitation, the present technique requires some additional procedures such as the submission of the patient to a general anesthesia in the hospital environment, as well as the use of a titanium plate and the confection of a mandibular prototype, which increase the treatment cost. Moreover, a professional with skills in maxillofacial surgery is required for the procedures of mandible exposure and fixation. Another consideration about this technique is the limited use of the functional guide during the implant placement, as it is difficult obtain a correct adaptation over the exposed mandible. Therefore, the correct (or an acceptable) positioning of the implants is highly dependent on the professional experience.

The present study concluded that the treatment with a titanium plate fixation previously to implant placement followed by immediate complete-arch implant supported rehabilitation is a safe and viable treatment for severely resorbed mandibles with high risk to fracture because only cortical bone is remaining. No biologic or major biomechanical complications were observed in 7 patients with follow-ups ranging from 12 to 84 months.

\section{Resumo}

Mandibulas severamente reabsorvidas com apenas osso cortical remanescente podem fraturar durante ou após a colocação de implantes. 0 presente relato de casos apresenta uma técnica para reduzir o risco ou as consequências da fratura mandibular. Pacientes com apenas osso cortical remanescente foram tratados com a fixação de placa de titânio na superficie frontal, previamente a colocação dos implantes, no mesmo procedimento cirúrgico. Próteses totais implanto-suportadas foram instaladas com carga imediata. Condições locais e sistêmicas dos pacientes que poderiam influenciar a sobrevivência dos implantes foram registradas previamente a cirurgia e durante o periodo de acompanhamento. Complicações biológicas e biomecânicas foram registradas. A condição dos tecidos peri-implante foi avaliada. Sete pacientes completaram o periodo de acompanhamento, variando entre 12 e 84 meses. Vinte e nove implantes foram colocados e nenhuma falha ou complicação biológica foi observada. A avaliação do tecido peri-implante demonstrou que a maioria dos implantes possuía tecido queratinizado $(89,5 \%)$. Nenhuma recessão marginal (plataforma do implante cervical à margem gengival) foi observada. Profundidade de sondagem mostrou-se normal, variando entre 0 e $3 \mathrm{~mm}$. Baixos escores de indice de placa ou sangramento à sondagem foram observados. Complicações biomecânicas envolveram perda de 4 e 1 fratura de parafusos protéticos. 0 uso da placa de titânio para fixação de mandibulas severamente reabsorvidas com apenas osso cortical remanescente pode ser considerado tratamento seguro, evitando alterações biológicas e maiores complicações biomecânicas no tratamento com próteses totais imediatas implanto-suportadas.

\section{Reference}

1. Wennerberg A, Albrektsson T. Current challenges in successful rehabilitation with oral implants. J Oral Rehabil 2011;38:286-294.

2. Mendonca DBS, Prado MMS, Mendes FA, Borges TF, Mendonça G, do Prado CJ, et al. Comparison of masticatory function between subjects with three types of dentition. Int J Prosthodont 2009;22:399-404.

3. Klemetti E. A review of residual ridge resorption and bone density. J Prosthet Dent 1996;75:512-514.

4. Almasri M, El-Hakim M. Fracture of the anterior segment of the atrophic mandible related to dental implants. Int J Oral Maxillofac Surg 2012;41:646-649.

5. Chrcanovic BR, Custódio ALN. Mandibular fractures associated with endosteal implants. Oral Maxillofac Surg 2009;13:231-238.

6. Lamas-Pelayo J, Peñarrocha-Diago M, Martí-Bowen E, PeñarrochaDiago M. Intraoperative complications during oral implantology. Med Oral Patol Oral Cir Bucal 2008;13:239-243.

7. Soehardi A, Meijer GJ, Manders R, Stoelinga PJW. An inventory of mandibular fractures associated with implants in atrophic edentulous mandibles: A survey of Dutch oral and maxillofacial surgeons. Int J Oral Maxillofac Implant 2011;1087-1093.

8. Mombelli $A$, van Oosten MA, Schurch $E$, Land NP. The microbiota associated with successful or failing osseointegrated titanium implants. Oral Microbiol Immunol 1987;2:145-151.

9. Dalago HR, Schuldt Filho G, Rodrigues MAP, Renvert S, Bianchini MA. Risk indicators for peri-implantitis. A cross-sectional study with 916 implants. Clin Oral Implants Res 2017;28:144-150.

10. Fabris V, Bacchi A. Fixation of a severely resorbed mandible for complete arch screw-retained rehabilitation: A clinical report. J Prosthet Dent 2016;115:537-540.

11. Chrcanovic BR, Kisch J, Albrektsson T, Wennerberg A. Analysis of risk factors for cluster behavior of dental implant failures. Clin Implant Dent Relat Res 2017;19:632-642.

12. Wen $X$, Liu R, Li G, Deng M, Liu L, Zeng XT, et al. History of periodontitis as a risk factor for long-term survival of dental implants: a metaanalysis. Int J Oral Maxillofac Implants 2014;29:1271-1280.

13. Gomes JA, Sartori IAM, Able FB, de Oliveira Silva TS, do Nascimento C. Microbiological and clinical outcomes of fixed completearch mandibular prostheses supported by immediate implants in individuals with history of chronic periodontitis. Clin Oral Implants Res 2017;28:734-741.

14. Annibali S, Cristalli MP, Dell'Aquila D, Bignozzi I, La Monaca G, Pilloni A. Short dental implants. J Dent Res 2012;91:25-32.

15. Edher F, Nguyen CT. Short dental implants: A scoping review of the literature for patients with head and neck cancer. J Prosthet Dent 2017;119:736-742.

16. Jemt T, Olsson M, Franke Stenport V. Incidence of first implant failure: A retroprospective study of 27 years of implant operations at one specialist clinic. Clin Implant Dent Relat Res 2015;17:501-510. 
17. Ciftçi $Y$, Canay $S$. The effect of veneering materials on stress distribution in implant-supported fixed prosthetic restorations. Int J Oral Maxillofac Implants 2000;15:571-582.

18. Camargos GV, Sotto-Maior BS, Silva WJ, Lazari PC, Del Bel Cury AA. Prosthetic abutment influences bone biomechanical behavior of immediately loaded implants. Braz Oral Res 2016;30: e65.

19. Sailer I, Philipp A, Zembic A, Pjetursson BE, Hämmerle CHF, Zwahlen M. A systematic review of the performance of ceramic and metal implant abutments supporting fixed implant reconstructions. Clin Oral Implants Res 2009;20:4-31.

20. Papaspyridakos P, Chen C-J, Chuang S-K, Weber H-P, Gallucci GO. A systematic review of biologic and technical complications with fixed implant rehabilitations for edentulous patients. Int J Oral Maxillofac Implants 2012;27:102-110.

21. Francetti L, Corbella S, Taschieri S, Cavalli N, Del Fabbro M. Mediumand long-term complications in full-arch rehabilitations supported by upright and tilted implants. Clin Implant Dent Relat Res 2015;17:758764
22. Roccuzzo M, Grasso G, Dalmasso P. Keratinized mucosa around implants in partially edentulous posterior mandible: 10-year results of a prospective comparative study. Clin Oral Implants Res 2016;27:491496.

23. Chung DM, Oh T-J, Shotwell JL, Misch CE, Wang HL. Significance of keratinized mucosa in maintenance of dental implants with different surfaces. J Periodontol 2006; 77:1410-1420.

24. Krennmair $S$, Weinländer $M$, Malek $M$, Forstner $T$, Krennmair $G$, Stimmelmayr M. Mandibular full-arch fixed prostheses supported on 4 implants with either axial or tilted distal implants: A 3-year prospective study. Clin Implant Dent Relat Res 2016;18:1119-1133.

25. Roos-Jansaker A-M, Renvert H, Lindahl C, Renvert S. Nine- to fourteenyear follow-up of implant treatment. Part III: factors associated with peri-implant lesions. J Clin Periodontol 2006;33:296-301.

Received October 5, 2018 Accepted January 19, 2019 